\title{
Official Authorities and Education in Financial Literacy - the Role of Central Banks in the Czech Republic and Poland
}

\author{
Dorota BEDNARSKA-OLEJNICZAK ${ }^{1,}$ Libuše SVOBODOVÁ $^{2 *}$ and \\ Jaroslava DITTRICHOVÁ ${ }^{2}$ \\ 1 Wroclaw University of Economics and Business, Wroclaw, Poland; dorota.bednarska-olejniczak@ue.wroc.pl \\ 2 University of Hradec Kralove, Hradec Kralove, Czech Republic; libuse.svobodova@uhk.cz, \\ jaroslava.dittrichova@uhk.cz \\ * Corresponding author: libuse.svobodova@uhk.cz
}

\begin{abstract}
The objective of this article is to analyse, on the example of Poland and the Czech Republic, actions undertaken by the central banks in the scope of economic and financial education. The study covers an analysis of applied tools and media in the framework of individual target groups. The adjustment of these actions to the long-term context - national strategies shaped by the central banks in accordance with the solutions recommended by OECD was also considered in the study. Undertaking comparative research stemmed, on the one hand, from the neighbouring location of the two countries, a similar level of economic development and a similar role of central banking in their respective economies, whilst on the other hand, from the analysis of study results concerning knowledge and economic awareness and financial competencies of inhabitants of both countries. In both countries, financial literacy is constantly improving. However, it is not possible to determine the direct impact of central bank activities and other educational activities.
\end{abstract}

Keywords: central bank; Czech Republic; education; financial literacy; Poland

JEL Classification: G20; M50; I22

\section{Introduction}

Economic and financial education of citizens has been a significant challenge for the governments of most countries for several years. This has resulted in OECD activities which are manifested by successive recommendations concerning possible actions to be taken by countries in this area. In some countries central banks play a special role in financial education. This article aims to analyse the comparative activities of the central banks of the Czech Republic and Poland in recent years to improve financial capability and financial literacy of citizens.

According to World bank definition "financial education is a tool for increasing consumer financial literacy" (World Bank, 2014). OECD (2005) describes the financial education as "the process by which financial consumers and investors improve their understanding of financial products, concepts and risks and, through information, instruction and/or objective advice, develop the skills and confidence to become more aware 
of financial risks and opportunities, to make informed choices, to know where to go for help, and to take other effective actions to improve their financial well-being". (OECD, 2005)

The definition of financial literacy used for adults to make it relevant for 15-year-old students is in the PISA assessment. The definition also incorporates students' ability to use financial knowledge and skills to meet challenges in the future. Financial literacy is knowledge and understanding of financial concepts and risks, and the skills, motivation and confidence to apply such knowledge and understanding in order to make effective decisions across a range of financial contexts, to improve the financial well-being of individuals and society, and to enable participation in economic life. (OECD, 2012)

The OECD/INFE for the purpose of measuring financial literacy amongst adults developed the subsequent working definition: "Financial literacy is a combination of the awareness, knowledge, skills, attitudes and behaviours necessary to make sound financial decisions and ultimately achieve individual financial well-being" (Atkinson \& Messy, 2012; OECD, 2016). This definition is now globally acknowledged and was also endorsed by G20 leaders in 2012 (G20, 2012).

The Ministry of Finance from the Czech Republic defined financial literacy as "Financial literacy is a set of knowledge, skills and attitudes necessary to achieve financial prosperity through responsible financial decision-making." (Ministry of Finance, 2021)

\subsection{OECD - the Financial Literacy Recommendation}

The OECD Council adopted the newest Recommendation on Financial literacy during the 2020 OECD Ministerial Council Meeting in October 29th. (OECD, 2020b) It presents a single, comprehensive, instrument on financial literacy to assist governments, other public authorities, and relevant stakeholders in their efforts to design, implement and evaluate financial literacy policies. It is part of a holistic approach to financial-consumer issues, where financial literacy, together with improved financial access, adequate consumer protection, and regulatory frameworks, are expected to support financial resilience and well-being.

The Recommendation covers three main areas:

- National strategies for financial literacy.

- Financial literacy and the various sectors of the financial landscape.

- Effective delivery of financial literacy programmes.

It takes into account the increased digitalisation of finance, it also looks at how to address the needs of vulnerable groups and draws on recent evidence and research.

The four content areas of knowledge and understanding essential issues for financial literacy are: (OECD, 2020a)

- money and transactions,

- planning and managing finances,

- risk and reward,

- the financial landscape. 


\subsection{Literature Review}

Significance of financial literacy, implementation of financial educational programmes, measuring financial literacy of citizens and related issues are frequently discussed in public, professional and academic environment. Financial well-being of individuals makes a large contribution. It is connected with high level of financial literacy, because financially literate individuals perform better their portfolio composition and they are more likely to participate in financial markets (Astuti \& Trinugroho, 2016), they are more secured to plan for retirement (Almenberg \& Save-Sodergergh, 2011) and rather accumulate higher amounts of wealth (Rooij et. al, 2011; Lusardi \& Mitchell, 2011; Lusardi \& Tufano, 2009). Developing effective financial educational programmes is essential in understanding financial literacy among young people. (Astuti \& Trinugroho, 2016)

The need for study focused specifically on measurement of financial literacy identified Marcolin and Abraham (2006). The need for financial education and to explain variation in financial outcomes such as investing, debt behaviour and savings are used as inputs to model financial knowledge indicators and/or financial literacy. Much fewer studies accent measurement of financial literacy as an objective. To highlight financial literacy tools, current limitations and to assist researchers in establishing standardized and commonly accepted measurement of financial literacy and overview of the importance is solved by Houston (2010).

Lessons learned from almost 25 years long experiences with different form of E-learning presented Gajewski (2016). All experiences were definitely positive. Negative were for example that widely used multimedia materials do not motivate poor students to learn. They prefer to watch the materials in a passive way in the learning process. Hedvičáková (2016) analysed literacy of students and their bank accounts.

In turn „lack of financial literacy was one of the factors contributing to ill-informed financial decisions and that these decisions could, in turn, have tremendous negative spillover" (OECD, 2012). Ciemleja et al. (2014), Kantnerová (2015) also analysed the level of financial literacy in different countries.

\section{Methodology}

Primary and secondary sources were used in the article. Secondary sources comprise information about education in the financial field and financial literacy in the Czech Republic, Poland and abroad, information collected from professional press, professional literature, discussions with professionals or previous participations in seminars and conferences relating to the aim of the article. The information gained from individual web portals, mainly from the Czech National Bank (CNB, 2021a) and Narodowy Bank Polski (NBP, 2021) are the primary sources. Those websites were gone throw and there have been looking information about financial education that the central banks operate. Then it was necessary to select, classify and up-date accessible relevant information from the numerous published materials that would provide the basic knowledge of the selected topic.

The objective of this article is to analyse, on the example of the Czech Republic and Poland, actions undertaken by the central banks in the scope of economic and financial education. 


\section{Results}

The research part contains analysis that was done in the Czech Republic and in Poland in January and February 2021.

\subsection{Solutions for Improving Financial Competencies by Official Authorities in the Czech Republic}

The revised Financial Literacy Standard (Standard financial literacy, 2017), which sets the target level of financial literacy for elementary and secondary school pupils was published on 20 July 2017 by the Ministry of Finance. Cashless payments, critical assessment of the supply of services and goods, protection of personal data, budgeting and comparison of liabilities and assets, renumeration, comparison of financial products, short- and long-term planning, age security, risk and emergence of borrowings, the consequences of defaults debt and over-indebtedness have been strengthened compared to financial literacy standards of 2007. The Framework Education Programs include the revised standard of financial literacy. Primary and secondary schools have to according to the National institute of education compare the revised standard of financial literacy with their school curriculum. School education program in the field of financial education during a transitional period have to be edited or completed.

- Web portal "Why Educate in Financial Literacy?"

In 2014, the Ministry of Finance of the Czech Republic launched a pilot version of the PSFV portal entitled "Why Financial Education?" which can be found at (Financial literacy or Why financial education?, 2021). Those websites are actualized and they contain actual information that are important for citizens.

The portal is beneficial electronic textbook for children, parents and also for teachers. Parents could use it themselves to direct in the complicated world of finance or to discuss about issues with children. Basic knowledge, issues from financial world and up-to-date information are provided. Positive is the combination of the theoretical basis with practical and actual information. More about this portal was analysed in (Hedvičáková \& Svobodová, 2018a; 2018b). More about financial education of pupils in the Czech Republic is in Hedvičáková et al. (2017) and Hedvičáková and Svobodová (2018c).

- The Czech National Bank

The Czech National Bank also reflects the changes in the financial market. In 2016 they have launched and operated web portal focused on financial literacy (Money on the run). In the previous years they have also informed and educated in the field of financial literacy.

The CNB assumes that:

- the health of the economy also depends on the financial health of the population

$\circ$ has the necessary information and know-how to contribute to strengthening financial and economic literacy

o it is important for her to have an informed citizen on her side $\rightarrow$ it facilitates the implementation of her mandate and prevents possible unfair practices in the financial market 
The CNB is part of the National Strategy for Financial Education. It participates in creating standards of financial education for primary, secondary and adult schools. The CNB also share experience and information in this area with other institutions such as the Ministry of Finance, the Ministry of Education, Youth and Sports, non-profit organizations, etc.

For high school students, they prepare: Economic Olympiads, experts to schools and students also compete with and essay focused on the financial literacy.

From its position as the "guardian" of fair conditions on the financial market, the CNB wants to take the following steps:

- To prevent unfair practices on financial market.

- To draw consumers' attention to the deliberate conclusion of contracts, be it loans, insurance, investments or savings.

In the last year there have been done changes in the sources presented by the Czech National Bank. Due this fact there are more information focused on the financial literacy divided according to needs of selected groups (see tab. 1). The new webpages (Financial and economic literacy, 2021) were launched in April 2020. There are used those sections on the websites.

- For teachers, pupils and students (teaching materials, useful links) -the main target group are students at age 10-13, but it can be used also for other groups.

- For the public and school groups (exhibitions, outreach groups)

- For the little ones

- For consumers

- Activities supported by the CNB

Table 1. Target groups and tools used for educational actions. (CNB, 2021b)

\begin{tabular}{|c|c|c|}
\hline No. & Target group & Tools \\
\hline 1. & For teachers, pupils and students & $\begin{array}{c}\text { Money, Bank and other financial institutions, } \\
\text { Personal finances and my budget, Finance triangle }\end{array}$ \\
\hline 2. & For the public and school groups & $\begin{array}{c}\text { Exhibition in Prague and in Brno, Preparation - the new } \\
\text { visitor's center, From 2019 - the new outreach agenda }\end{array}$ \\
\hline 3. & For the little ones & $\begin{array}{c}10 \text { coloring pictures that includes the basic information } \\
\text { about the Czech National bank, its functions, mission etc. }\end{array}$ \\
\hline 4. & For consumers & $\begin{array}{c}\text { The data, information, videos and statistics about } \\
\text { financial market. }\end{array}$ \\
\hline
\end{tabular}

- Web portal "Money on the run"

The site Money on the run (CNB, 2021c) was designed by the Czech National Bank for young people aged 18-35. To educate them in a comprehensible form was the main purpose of the websites. Three sections that constitutes important issues are:

$\circ$ budgeting,

- financial services,

$\circ \quad$ life events. 
The site also included a glossary of terms, quizzes and ten commandments about money. The portal can be used also in school practice. Some issues may be better used for secondary school pupils than elementary ones.

In the last two years the websites were actualized and they have broaden the topics on: insurance, loans, savings, pension, family, housing, car, money and debts.

\subsection{Solutions for Improving Financial Competencies by Official Authorities in Poland}

Many different institutions are involved in the financial education in Poland, both those strictly educational in nature such as higher education institutions as well as banks, foundations, scientific associations and government institutions (full list available on ZBP, 2020 by Association of Polish Banks (ZBP, 2020)). One of the entities realizing financial education programmes is central bank - the National Bank of Poland (NBP). Within the process of financial education in Poland, a special role is played by the Council for Financial Education which was established in 2019. It comprises the representatives of the Ministry of Finance, the NBP, the Financial Ombudsman and the Polish Financial Supervision Authority. The key goal of the Council for Financial Education is to propagate the knowledge regarding public finance. The Council sets out the directions and paths of realizing the financial tasks under the National Education Fund, among others, educational campaigns and IT campaigns targeted at increasing the financial awareness of the society and elaborating the strategy of financial education as well as monitoring its realization.

To date, no national strategy for financial education has been elaborated the implementation of which is recommended by OECD. Currently, actions are ongoing targeted at elaborating its basic assumptions and directions of actions. The strategy of financial education ought to cover the whole society, with special consideration of individual social groups (such as women, seniors, persons with low income, inhabitants of villages, immigrants etc.). It is thus vital to properly identify those entities and their activities on the financial market, which will permit the identification of the types of financial instruments which might constitute the subject of education and, ultimately, which might impact the choice of educators and the content and the tools of educational programmes. The following basic assumptions referring to the conduct of financial education in Poland, from amongst those formulated by the Financial Ombudsman deserve special attention (Golecki, 2020):

- Applying cognitive results in behavioural psychology in the programmes of financial education and, as a result, combining traditional teaching methods with the new ones, based on studies of behavioural nature.

- There is no single universal approach that would be effective for all target groups in the programme of financial education, both with respect of the clients of financial market entities and, potentially, with respect of the institutions on that market. Initial actions in the scope of shaping the programmes of education will be targeted at regular monitoring of the state of financial awareness of society. 
- The Financial Ombudsman will support the forms of financial education that to which the instructors and the participants of trainings will be able to build relations resulting in shaping trust of these participants towards the state and the free-market institutions.

- The programmes of financial education that introduce the techniques of self-control and assertiveness while allowing to avoid excessive expenditure and debts will be supported.

- The programme of financial knowledge will contribute to acquiring practical skills.

- Educational programmes that introduce computer games for children and the youth and contain significant elements in the scope of finance will be promoted. Emphasis will be placed also on the use for educational purposes of mobile applications and websites.

- Actions carried out in the framework of financial education will be inclusive and will not exclude any group on account of any specific limitations - either language-specific, intellectual or age-based.

The educational and information activity is a crucial element of NBP mission. It covers undertaking actions targeted at disseminating knowledge about the principles of functioning of the financial market, encouraging entrepreneurial attitudes, shaping the responsibilities while undertaking financial decisions, increasing the level of knowledge of economic issues, popularizing the knowledge regarding national economic heritage and promoting modern attitudes impacting the shape of social capital (NBP, 2020). As one may notice, the educational activity of NBP overally refers to the popularization of economic knowledge, however, it largely focuses, particularly on financial education.

Formerly, educational actions carried out by NBP were regulated by the guidelines in "Strategy for economic education of the National Bank of Poland for the years 2010-2012". Currently, this strategy has not been formulated, nevertheless, actions of NBP reflect to some extent realization of the directions and assumptions provided for by it. The above-specified document indicated three basic types of actions in the scope of realizing by NBP of education sense stricto (NBP, 2020): a) deepening and developing economic education on all stages of school and academic education; b) information-training actions targeted at improving economic awareness of the inhabitants, directed at various groups of recipients; c) initiating public debates regarding financial phenomena and conducting courses concerning economic knowledge, activating various social groups (NBP, 2010). Tools of conducting educational activities adjusted to the specificity of target groups have been presented in Table 2.

In the framework of education in the scope of economics and finance, currently NBP:

- announces and realizes cyclical contests,

- organizes trainings,

- supports and realizes educational programmes,

- provides educational resources,

- provides knowledge via Money Centre,

- researches financial knowledge of the Poles (NBP, 2020b). 
Table 2. Target groups and tools used for educational actions. (NBP, 2010)

\begin{tabular}{|c|c|c|}
\hline No. & Target group & Tools \\
\hline 1. & $\begin{array}{c}\text { Leaders of environments with an impact on } \\
\text { shaping economic awareness, Journalists, } \\
\text { Teachers of economic subjects and academic } \\
\text { lecturers specializing in economic areas }\end{array}$ & $\begin{array}{c}\text { Post-graduate studies and courses, } \\
\text { trainings, public debates, contests }\end{array}$ \\
\hline 2. & $\begin{array}{c}\text { Consumers and persons using financial } \\
\text { instruments }\end{array}$ & $\begin{array}{c}\text { Educational, promotional actions in the } \\
\text { media (press, radio, television, internet) }\end{array}$ \\
\hline 3. & $\begin{array}{c}\text { Persons from environments characterized by a } \\
\text { lower level of economic awareness }\end{array}$ & $\begin{array}{c}\text { Training activity (trainings, coaching, } \\
\text { mentoring), network of communal } \\
\text { libraries as a distribution channel of } \\
\text { knowledge and finances as well as } \\
\text { economics }\end{array}$ \\
\hline 4. & Persons using economic knowledge at work & Courses, trainings, \\
\hline 5. & Students (including students of economics) & $\begin{array}{c}\text { Meetings with business representatives, } \\
\text { business fairs, trainings, online education, } \\
\text { conferences, scholarships }\end{array}$ \\
\hline 6. & & Pupils \\
& & $\begin{array}{c}\text { Lectures, workshops, trainings, courses, } \\
\text { contests and other activation methods, } \\
\text { shaping teaching programmes }\end{array}$ \\
\hline
\end{tabular}

Apart from the discussed actions realized by NBP, one ought to point out a number of initiatives in the scope of economic and financial education that NBP covered with its support. These include, among others: XXXI Economics Olympics organized by the Polish Economic Society, issued by the Foundation of the 100th Anniversary of Poland's Regaining Independence an album "History of money goes on", organization by the Jacek Maziarski Foundation of two issues of trainings in the scope of economic education, prepared in the framework of the "Community Academy" project. Economic education of local society leaders", the project "Modern and safe finances for seniors" organized by the Polish Federation of Third Age University Associations, the programme 'Think, decide, act finances for the youngest" organized by the Association of Shaping Financial Education etc.

\subsection{Access Channels and Forms of Conducting Educational Actions in the Czech Republic and Poland}

These actions, depending on the type of recipients, were and still are conducted by CNB and by NBP by means of various channels of access and educational policy tools. Both countries have almost the same access channels and forms of conducting educational actions (see Table 3).

Actions conducted by CNB and NBP in the scope of economic education (including financial) are addressed to two main groups of recipients:

- Indirect: leaders of environments having an impact on shaping economic awareness, journalists, teachers of economic subjects and academic lecturers specializing in economic areas.

- Direct: these are consumers and persons using the financial instruments, persons from environments characterized by a lower level of economic awareness (lagging regions in terms of economy - such as village inhabitants), persons using economic knowledge at 
work, in particular, persons performing public trust professions (journalists, lawyers, public administration employees), students, pupils (CNB, 2021; NBP, 2010).

Table 3. Access channels and forms of conducting educational actions. (CNB, 2021; NBP, 2010)

\begin{tabular}{|c|c|c|}
\hline No. & Access channel & Forms of conducting educational actions \\
\hline 1. & $\begin{array}{l}\text { Media (press, } \\
\text { radio, television, } \\
\text { internet, external } \\
\text { carriers) }\end{array}$ & $\begin{array}{l}\text { Educational-information campaigns: programmes on TV and on the } \\
\text { radio, press extras, multimedia materials (presentations, films, games } \\
\text { regarding economics), banners, streams, questionnaires - displayed } \\
\text { on the internet }\end{array}$ \\
\hline 2. & Publications & $\begin{array}{c}\text { Permanent publications, serial and closed brochures, multimedia } \\
\text { publishers }\end{array}$ \\
\hline 3. & Public debates & Conferences, seminars, debates \\
\hline 4. & Contests & $\begin{array}{l}\text { Contests concerning economic knowledge, subject Olympics, } \\
\text { competitions for the best academic dissertation }\end{array}$ \\
\hline 5. & Studies & Academic studies, post-graduate studies \\
\hline 6. & Trainings & $\begin{array}{l}\text { Trainings, workshops, lectures, courses, training games, online } \\
\text { education - e-learning, coaching and mentoring }\end{array}$ \\
\hline
\end{tabular}

\section{Discussion and Conclusion}

The analysis of financial education activities undertaken by Poland and the Czech Republic's central banks indicates the existence of significant differences in the adopted concepts of activities. In both countries, central banks expanded their activities in broadly understood financial education more than ten years ago. However, it should be noted that in the Czech Republic, the central bank is formally inscribed in successive government strategies for financial education, while in Poland, there are still no such strategies, and the central bank activities are implemented in isolation from the actions of other institutions. Another issue is the preferred forms of educational activities. In the Czech Republic, elearning plays a vital role in the educational activities of the central bank. As it can be observed, a large part of these activities is of on-line and interactive nature, while in Poland, despite educational portals with non-interactive content, traditional forms of education are preferred.

We should also note that only the covid-19 pandemic increased the number of interactive educational programmes in Poland. Despite the identification of specific target groups (children, students, seniors, digitally excluded people, etc.) in the case of Poland, educational programmes are mainly dedicated to children and young people. In the case of the Czech Republic, it seems that educational activities are dedicated to a wider audience. However, taking into account the compliance of educational activities with the OECD recommendations mentioned in the article, it should be noted that both in the Czech Republic and Poland, most of these recommendations are taken into account in the educational programmes of central banks.

Can we therefore conclude, on the basis of these differences, that the solutions adopted in either country are more advantageous or have better results? The answer is not simple or unequivocal. First of all, central banks in both countries (despite the lack of uniform strategy for financial education in Poland) are elements of the whole system of financial education and it is not possible to indicate the consequences of their actions only. Secondly, the aggregate results of the 2020 Adult Financial Literacy Survey are almost identical for the 
Czech Republic and Poland (OECD, 2020a) and are at the level of the G20 average. This is a positive change compared to 2016 (OECD, 2016) when both countries were significantly below the average, with the Czech Republic having a significantly higher level of financial literacy. However, these changes may have been influenced in part by the new structure of the survey instrument in 2020. Thirdly, the analysis of partial results of the OECD survey indicates that there are differences in the levels of financial literacy (here Poles have a higher level), financial behaviour (also a slightly higher level in adult Poles) and attitudes to longerterm financial planning (here Czech adults have a significantly higher level).

A comprehensive view on evaluation of cluster initiatives is presented in Bureš et al. (2012). It is possible to recommend to use clusters to be more effective. The next important issue is also technological readiness of the countries. The situation in the Czech Republic was solved in Svobodová and Hedvičáková (2017) and citizens are prepared to use technologies for education. The central banks of Poland and the Czech Republic acting actively in the field of financial education support growth of financial literacy of the society. However, due to the multitude of entities implementing such activities, it is not possible to indicate the scale of their impact. At the same time, it can be indicated that the implemented educational programmes are part of the CSR concept of banks popular in commercial banks (BednarskaOlejniczak, 2017). It is all the more understandable that central banks belong to the group of public trust institutions which should influence the improvement of financial security of citizens. Important is also price information asymmetry and financial education solved in Soukal (2015).

COVID-19 has also impact on the financial products and literacy. In the Czech Republic was one of the changes in mortgages, where the credit moratorium allowed ordinary consumer borrowers, self-employed persons and firefighters to defer repayment of loans and mortgages agreed before 26 March 2020, until the end of July or until the end of October (Ministry of Finance, 2020).

Acknowledgments: We would like to thank to project "SPEV - Economic Impacts under the Industry 4.0 / Society 5.0 Concept ", 2021, University of Hradec Králové, Faculty of Informatics and Management, Czech Republic" and to Anna Borkovcová.

\section{References}

Astuti P. H., \& Trinugroho, I. (2016). Financial literacy and engagement in banking. Journal of Economics and Economic Education Research, 17(1).

Almenberg, J., \& Save-Soderbergh, J. (2011). Financial Literacy and Retirement Planning in Sweden (Netspar Discussion Paper 01/2011-018). http://arno.uvt.nl.

Atkinson, A., \& Messy, F. (2012). Measuring Financial Literacy: Results of the OECD / International Network on Financial Education (INFE) Pilot Study (OECD Working Papers on Finance, Insurance and Private Pensions, No. 15). OECD Publishing. https://doi.org/10.1787/5k9csfs90fr4-en

Bednarska-Olejniczak, D. (2017). Edukacja Finansowa Jako Przejaw Społecznej Odpowiedzialności Banków. E-Mentor, 2017, 42-47. https://doi.org/10.15219/em72.1325

Bureš, V., et al. (2012). A Comprehensive View on Evaluation of Cluster Initiatives. In J. Politis (Ed.), Proceedings of the 8th European conference on management leadership and governance (pp. 74-79).

Ciemleja, G., Lace, N., \& Titko, J. (2014). Towards the Practical Evaluation of Financial Literacy: Latvian Survey, Procedia - Social and Behavioral Sciences, 156(26). https://doi.org/10.1016/j.sbspro.2014.11.111

CNB. (2021a.) CNB. https://www.cnb.cz/en/ 
CNB. (2021b). CNB Financial and economic literacy. https://www.cnb.cz/cs/o_cnb/financni-a-ekonomickagramotnost

CNB. (2021c). CNB Money on the run. https://www.penizenauteku.cz/

G20. (2012). G20 Leaders Declaration. http://www.g20.utoronto.ca/2012/2012-0619-loscabos.pdf

Gajewski, R. R. (2016). Pitfalls of E-education: from multimedia to digital dementia? In Ganzha, M., Maciaszek, L., \& Paprzycki, M. (Eds.), Federated Conference on Computer Science and Information Systems (pp. 913-920). https://doi.org/10.15439/2016F356

Golecki, M. (2020). Kierunki edukacji finansowej Rzecznika Finansowego - Rzecznik Finansowy (Financial Education Strategy Basic Assumptions, Financial Ombudsman).

Hedvicakova, M. (2017). Key study of bank accounts for young people with using multi-criteria optimization and fuzzy analysis. Applied Economics, 49(17), 3599-3610. https://doi.org/10.1080/00036846.2016.1265073

Hedvičáková, M., Svobodová, L., Dittrichová, J., \& Král, M. (2017). Financial literacy and money management of the pupils in the Czech education system. In Novák, P., Jurigová, Z., Kozubíková, L., \& Zlámalová, J. (Eds), Proceedings of the 8th International Scientific Conference Finance and Performance of Firms in Science, Education and Practice (pp. 244-259).

Hedvicakova, M., \& Svobodova, L. (2018a). Web portals to support financial literacy in the Czech Republic. Advanced Science Letters, 24(4), 2948-2952(5). https://doi.org/10.1166/asl.2018.11102

Hedvicakova, M., \& Svobodova, L. (2018b). Web Portals to Support Financial Literacy in Blended Learning in the Czech Republic. Lecture Notes in Artificial Intelligence (Vol. 11056, pp. 409-418). Springer Berlin Heidelberg. https://doi.org/10.1007/978-3-319-98446-9_38

Hedvicakova, M., \& Svobodova, L. (2018c). Solutions for Higher Competence in Financial Literacy of Pupils at Secondary School in the Czech Republic. Lecture Notes in Computer Science (Vol. 11195, pp. 387-396). Springer Berlin Heidelberg. https://doi.org/10.1007/978-3-030-02131-3_35

Huston, S. J. (2010). Measuring Financial Literacy. The journal of consumer affairs, 44(2), 296-316. https://doi.org/10.1111/j.1745-6606.2010.01170.x

Kantnerová, L. (2015). The Comparison of Level of Financial Literacy in Four Countries. In E. Pastuszková, Z. Crhová, J. Vychytilová, B Vytrhlíková, \& A. Knápková (Eds.), Proceedings of the 7th International Scientific Conference Finance and Performance of Firms in Science, Education and Practice (pp. 559-570).

Lusardi, A., \& Mitchell, O. S. (2011). Financial Literacy and Planning: Implications for Retirement Wellbeing. University Press, Oxford.

Lusardi, A., \& Tufano, P. (2009). Debt Literacy, Financial Experiences, and Overindebtedness (NBER Working Paper n. 14808). NBER.

Marcolin, S., \& Abraham, A. (2006). Financial Literacy Research: Current Literature and Future Opportunities. http://ro.uow.edu.au/commpapers/223/

Ministry of finance. (2017) Standard financial literacy. https:/www.mfcr.cz/cs/aktualne/aktuality/2017/standardfinancni-gramotnosti-29163

Ministry of Finance. (2020). The general deferral of repayments is ending, lenders will help clients individually. https://www.mfcr.cz/cs/aktualne/tiskove-zpravy/2020/plosny-odklad-splatek-konci-poskytovatel-39851

Ministry of Finance. (2021). Financial literacy or Why financial education? https://financnigramotnost.mfcr.cz/cs/aktuality

NBP. (2021). NBP. https://www.nbp.pl/

NBP. (2010). Strategy of economic education of the National Bank of Poland for the years 2010-2012). http://grafik.rp.pl/grafika2/394296

NBP. (2020). About NBP. Educational and information activity. https://www.nbp.pl/home.aspx?f=/o_nbp/informacje/dzialalnosc_edukacyjna.html

NBP. 2021. Narodowy Bank Polski (Journal of Laws of 2019, item 1810 and Journal of Laws of 2020, item 568) [WWW Document]. URL https://www.nbp.pl/en/aktyprawne/the_act_on_the_nbp.pdf (accessed 2.1.21).

OECD. (2005). Recommendation on Principles and Good Practices for Financial Education and Awareness, OECD. https://www.oecd.org/daf/fin/financial-education/35108560.pdf

OECD. (2012). PISA 2012 Financial literacy assessment framework. http://www.oecd.org/pisa/pisaproducts/46962580.pdf

OECD. (2016). OECD/INFE International Survey of Adult Financial Literacy Competencies, OECD. http://www.oecd.org/daf/fin/financial-education/OECD-INFE-International-Survey-of-Adult-FInancialLiteracy-Competencies.pdf 
OECD. (2020a). PISA 2018 Results. https://www.oecd-ilibrary.org/docserver/48ebd1baen.pdf?expires=1613129637\&id=id\&accname=guest\&checksum $=$ C488087B6CA75B53782D4455075FC840

OECD. (2020b). OECD Recommendation on Financial Literacy. http://www.oecd.org/finance/OECDRecommendation-on-Financial-Literacy.htm

Rooij van M., Lusardi, A., \& Alessie, R. (2011). Financial Literacy and Retirement Planning in the Netherlands. Journal of Economic Psychology, 32, 593-608. https://doi.org/10.1016/j.joep.2011.02.004

Soukal, I., \& Draessler, J. (2015). Could Financial Literacy Overcome Price Information Asymmetry: Empirical Study. In J. Krajíček, \& V. Kajurová (Eds.), 12th International Scientific Conference on European Financial Systems 2015 (pp. 528-535).

Svobodová, L., \& Hedvičáková, M. (2017). Technological Readiness of the Czech Republic and the Use of Technology. Lecture Notes in Business Information Processing (Vol. 299, pp. 670-678). Springer Berlin Heidelberg. https://doi.org/10.1007/978-3-319-65930-5_53

World Bank. (2014). Financial education programs and strategies: Approaches and available resources. https://documents.worldbank.org/en/publication/documentsreports/documentdetail/901211472719528753/financial-education-programs-and-strategies-approachesand-available-resources

ZBP. (2020). Mapa edukacji finansowej (Financial education map). https://www.zbp.pl/getmedia/fab163a0-ed6d47ef-a434-0dc2c1f115e4/Mapa_6-cz-2-organizatorzy-edu-fin 